\title{
RESISTING DOMINANT CULTURE IN THE LONELY LONDONERS: A CRITICAL DISCOURSE ANALYSIS
}

\author{
Kawa Sherwani ${ }^{1 *}$, Saman Dizayi ${ }^{2}$ \\ ${ }^{1}$ Assist. Prof. Dr., Erbil Polytechnic University, Iraq, kawa@epu.edu.iq \\ ${ }^{2}$ Dr., Erbil Polytechnic University, Iraq, saman.dizayi@epu.edu.iq \\ ${ }^{*}$ Corresponding Author
}

\begin{abstract}
This paper investigates the resistance of immigrants to cultural dominance of London society in The Lonely Londoners, a postcolonial novel by Sam Selvon. The Lonely Londoners (1956) depicts the miserable life of Caribbean people who migrated in hope to find better condition of living than their countries. The paper furnishes a theoretic ground for analyzing the discourse of the novel which presents the subject of resisting dominant culture throughout events and language used by the novelist. The paradigm of immigrants, their trauma and shock have always been the spot line of discussion after WWII. Through the colonial history there was a dominant discourse of Western cultural superiority imposed on colonized, with the postcolonial era a different discourse emerged through intellectual presentations such as Fanon, Said, Bhabha ideas and others who enlightened literary theory and criticism and theorized resistance and cultural identity. Thus, this paper will critically analyze the discourse of resistance of Postcolonial people in exile to ascertain their existence and identity.
\end{abstract}

Keywords: Post colonialism, Discourse analysis, Resistance, Identity

\section{INTRODUCTION}

During the $18^{\text {th }}$ century and the most part of the $19^{\text {th }}$ century, the western countries have taken over the major part of the world. With different countries including the Netherlands, Portugal and especially the Britain have made countless colonies to the countries across the globe. This colonial era has led the world to have that effect of white supremacy in their mind which emphasizes on the point that a person is considered superior purely by skin color that a person possesses. Hence after this particular time, when the concept of colonization was at a decline, the majority of the people from the colonized countries sought better future heades towards the above mentioned European countries. While it may sound all glory and success however the reality was a bit different (Mills, 2017, pp. 475-487).

Lonely Londoners is also an impression of the problems and difficulties that the immigrants faced while migrating to the Britain. The racism which was depicted by the local Londoners in particular with the black people who were migrating from Trinidad and other West African countries were subjected to the cultural dominance and white supremacy throughout the country (Bonds \& Inwood, 2016, pp. 715-733). The novel of Sam Selvon was written in a friendly and light heartened tone but this fact is undeniable that it surely raised a very valid point which was the need for resisting the dominant culture. The the Caribbean people who were migrating to the Britain were treated very badly, not only it was difficult for these black immigrants to find work, but it was also extremely difficult to have adequate living condition in the country this is due to the racism that existed because of the cultural diversity present among different groups of people (Ungar, 2015, 
(pp. 37-48). Hence a sense of dominance was created which led to much discrimination over almost every aspect of living during that particular time (Apple \& Christian-Smith, 2017, pp. 1-21).

Dominant culture basically describes the sense of superiority that exists between two different ethnicities within a particular domain. Speaking strictly for colonial times, this sense of supremacy and dominance was not because of the superiority of intellect or any other factor. The novelist made special emphasis on this matter which is defined by the fact that during the post-colonial era where there were many problems faced the whole black community living in London at that time (Kapur, 2017, pp. 61-112).

\section{METHODOLOGY}

The methodology of the paper is critical discourse analysis. It asses the text of a literary work of a novel entitled The Lonely Londoners taking the whole body of the work as field linguistic area beside its literary and social values. Thus, the paper investigates the concept of resistance in the novel written by Sam Selvon according to critical discourse analysis, and determines the method of addressing the notion of resistance The Lonely Londoners adopted throughout literary elements the novelist practiced.

\section{CRITICAL ANALYSIS OF THE NOVEL}

The Lonely Londoners depicts and very accurately portrays the harsh conditions which the black Caribbean faced who arrived to the Britain after the decolonization period (Dutta, 2015, pp.123-143). The concept behind the immigration was mainly to induce a much better lifestyle and to adopt the same methods in the land of the European in the hope that this can bring a more promising and a better future for the individuals. When these black Caribbean arrived in London, they have faced a totally flip scenario (Moss, 2017, 11-32). Not only they were not component enough in terms of economy and financial stability, apart from that it was also very difficult for these new immigrants to settle into the country with the fact that the country was against the policy of the immigration and was adamant in getting rid of all the black immigrants that have arrived in the country (Dutta, 2015, pp.123-143).

The majority of the black people already had that feeling of dominance in their mind, mainly because of the colonization factor. Being psychologically influenced by the European, having the perspective that white skinned people are much better at dealing with life than other led to the belief that undermines one's own authority. This is due to their own appearance. This led to a situation where there was a confidence factor which played in the minds of these immigrants. Hence; they were not even able to raise their own voice and belief in themselves (Escobar, 2018).

As people often say, the secret of an effective book is a charming young woman and a happy ending. After all, there were not many good young men in the lonesome London of Samuel Selvon that We read at the university in the early nineties. Tanty, the most prominent female character in the book, is an older intruder and wants is to explore as many shop fronts in the store as if she were "at the store home." In addition, consumption - usually not yet completed - has no clear conclusion, as the hero Moses Aloetta still reflects his future before the Thames, considering the London fog dominant theme of the novel (Dutta, 2015, pp.123143).

The epic was published in 1956 and took place in London in the 1950s, referring to the Caribbean settlers who landed in 1948, which is referred to as "Wind Rush" (Bonds \& Inwood, 2016, pp. 715-733). Many of the immigrants were fighting for Britain in the UK. After World War II When they could not establish themselves in their island network, they decided for a more open door in the "house". The United Kingdom was initially referred to as the source of abandonment, as it developed in the late 1950s, and became targets of racial contempt and xenophobia. It was even advanced to the enemy to announce the parliamentary movement (Dutta, 2015, pp.123-143).

Poverty will hit the reader in the first absolute sentence: "Dark winter nights, some unrealistic phenomena in London, a fog eagerly sleeping in the city, lights appearing in the haze, as if not London, just a special place on another planet." The Caribbean settlers who found that Moses went to Waterloo in London could be another planet (Bonds \& Inwood, 2016, pp. 715-733). "They were invited in cold weather and the columnists asked why they could not stay in their homeland, and spoke of his confusion like Sir Galahad, wearing a summer suit and slipping out of the train in that gruesome winter when he was asked if they seemed to be shocked, and with that ingenious step, the creators quickly created the "other" of these aliens who proved their equipment to accept English was bad, Peru noted, breaking their blow (Dutta, 2015, pp.123-143). The Lonely Londoners is an important novel that has the duty to speak without representation to this session. Because immigrants live at the margins of society, few people know their reality, for example: people who work in an environment or in an office assume that they do not exist. Moses, the Labor Department veteran, explained what Galahad had planned for this new company: Provided you have the opportunity to get in, 
you'll first have to get a job to see if they need cats and animals to keep him inside (Bonds \& Inwood, 2016, pp. 715-733). "When the cops claimed that they were from the office, and the general population told them by claiming that they could not enter, this would cause a lot of inconvenience. From the outside they do not need shadow pillars, they just say that they regret the opportunity" (Dutta, 2015, pp.123-143).

It is this collection of personal shadows that drives Selvin's story into the sun (Dutta, 2015, ). Various authors imitate his example, especially Colin McGinnis, with swords and absolute beginners. McGinnis said that these people have very few conversations, especially in the media: "How can one avoid current books or export the current status of Finger Fish \& Chips and the weekly magazine section absolutely amazing? It is amazing and almost no one can find it is now in England (Dutta, 2015, pp.123-143).

Individual Londoners bring the benefit to the fore by consciously using the plot structure called "calypsonian" and "ballad." This verbal history of equipment is inseparably expressed in non-standard English books, and the language popular on the island is used for exchange and account recording. From time to time, Peruer was struck by the Creator's return to Standard English, particularly in the phrase "continuous river", which represents summer activities and their erotic and experiential experiences (Bonds \& Inwood, 2016, pp. 715733).

Selvin began to write a book in plain English. How happy are you? because no standard English can capture the anger, enthusiasm or belief of the character. The true quality of this book undoubtedly lies in its characteristics. Selvon personally recognized these workers: he was a member of the Caribbean Conference, including VS Naipaul, George Lamming, Andrew Salkey, and Derek Walcott, who came to London in the 1950s (Adams, 2017, pp. 41-55).

If this is the case, Selvon spends much more time than the others calculating the number of shadows of ordinary workers and their experience of isolation in the city. Some experts describe "Lonely Londoner" as a real life story (Johansson \& Vinthagen, 2016). The life story of this meeting is less than usual. This is a life connection. Regardless of what the meeting brings, the creators will be careful to attract them: Selvon introduces a way to provide the most appropriate and intangible details with a wide range of meanings (Ellis, 2015).

Their characters are not holy people, but tanks, liars, weeds and rock hunters. Whatever it is, by using the generalizations that white society has created in obscure societies, it can stand on them and create real, multi-dimensional characters. After a short while we ignored the difference between them. Then it was basically traditional people trying to survive in a distant and barbaric society committed to suppressing them (Dutta, 2015, pp.123-143). We share your fear, nervousness, disappointment and joy. Most importantly, we value their strength because they organize the driveway and the window says, "Keep the water white" (Adams, 2017).

Every character is added to a public image: There is a strong and despicable Tanty that finally gives regional traders the opportunity to lend credit to their Caribbean customers. "Bart, when he sees a comrade parting, one guy begs for a banquet, beard cannot feed, so he does not have to change the pound and the simplicity of his partner "; There is also a great single city whose lives are driven by two dreams: to win big prizes in the pool and to visit the huge city of the world. If you win immensely, your desire is "to buy a complete road and make it available to young people ... I'll send a warning on each leaf:" (Ellis, 2015). Keep the color of the water, no room for white clothing. Then there is a cap, "lazy and gentle and resentment can only be coordinated by their special and attractive qualities for women" (Adams, 2017, pp. 41-55).

However, this is not just a novel about race and survival, but also a novel about the city. Selvons declaration in London after the war was so innovative and suggestive that people liked life that existed in that way (Ellis, 2015). It makes the seemingly indestructible difference between the grubby and ordinary street workers of Harrod and Notting Hill and their wealthy communities in Belgravia, Knightsbridge and Hampstead (Adams, 2017, pp. 41-55). This shows that London is not a city, but it is a summary of many small cities: "Some people live in London, they do not know what's happening in the next room, of course, more on the street or how others live divided into small universes, you stay on a planet with places, you know nothing about the end result, except what you see in the newspaper (Johansson \& Vinthagen, 2016, pp. 417-435).

It is easy to imagine how sad these settlers are, and their memories of these magnificent island nets are only sanctuary in these few minutes. Although it's a book about pastors and distances, it's definitely not a frustrating book (Ellis, 2015, pp. 178-189). Even if his character had the most terrible pain, Selvin could grasp the intelligence in the situation. Whenever Galahad decided to bring a pigeon out of Kensington Gardens for dinner, claiming to be a cold winter and wishing, he would be followed by an old man who took action to call the police. Like all great comics, Selvon uses satire to achieve the original expression (Ellis, 2015). With the emergence of the pigeons, we have seen a limited view of the world: one that considers 
pigeons as nutritious, and the other that prefers a person starves before pigeons are used as food. Moses' protest in front of Galahad emphasized this difference: "Boy, you took a big risk ... Do you think it's Trinidad? These pigeons should improve the resort there, not eat" (Bonds \& Inwood, 2016, pp. 715-733).

The message of a lonely Londoner is more important today than in the UK. Although we are gradually separating the social order based on race, ideology, and religious boundaries. The novel says, "We're all dead, no matter what they do during their lifetime, they're dead." The narrative issues seem to capture Moses' delusion rather than reflecting the narrator's point of view. This deep focus depends on using the free anomaly style. Moses would not say it here, but his translation of consciousness is, as if he were the third person in the narrator, not the main character (Dutta, 2015, pp. 123-143).

The close relationship between the voice of the story and the voices of the dark Caribbean characters is one of the most creative elements of Selvin's creation in The Lonely Londoners, which produced the structure and theme of Kathie Birat. Influencing Influence: Speech, especially the characters, seeks a suitable language to capture their experience, the theme of history. He reiterated that nature has both new influences and people in the world The Caribbean influences what makes the state of London so special for those who understand it (Dutta, 2015, pp.123-143). Selvon was by no means the first essayist to explore the inaccuracy of the West Indies: in 1934, Jean Rhys (1890-1979) focused on a young woman in her novel The Journey of Darkness (Johansson \& Vinthagen, 2016). The Caribbean is trying to make a living in London. Selvon was not the first person to have an imaginative performance in the opposite direction, but his experiment with popular voices as he examined his subject and his story went on was something new at the time: "I want to confirm that I am not against it. The main author of the Caribbean, and I used jargon in a complete novel where he was used for accounts and exchange (Ellis, 2015).

The academic style of Selvon will be discussed separately later, but the focus is on study of the entire novel. If we try to over-emphasize the new terms or terms, we will get an overview of the nature and structure of your account (Dutta, 2015, pp.123-143). The basic discourse on the structure of the novel creates relevance that relates in different ways to our concept of "written works" of individual Londoners, including other forms of history, whether artistic or inappropriate. In his first experience with the original version, Nastu provided through the structure of the fragment the influence of Calinosa's narrative method of Servin Trinity, "clearly understood by his thoughts, behavior, jealousy, and acute political imitation." "We can finally find a mediating voice without the education of the worker, which refers to the notion of their own social issues, not the decay of scholars and authors." A conscious view in non-western and non-artistic illustrations, the test of language and academic structure proposed in Caribbean terminology is improved and language is promoted (Dutta, 2015, pp.123-143).

In the first "The Lonely Londoners" publication by Kenneth Ramsheed in 1985, he proposed the possibility of linking the Selvin method with the oral narrative habit in the social order (Ellis, 2015, pp. 178-189). Not ambiguous, without printed text. Moreover, it uses the state of the novel as compound content because it is "based on what is used in verbal and verbal notation without losing the way of life as a work". The verbal expression reflects the evidence of the traditional origin of the abstract, which gives power to the printed text. Regardless of their "compounded" state, the content language organizes the sounds of the art code when constructed (Johansson \& Vinthagen, 2016, pp. 417-435).

The accent of the above basic visions may vary, but the unifying idea of connecting them is the convenient connection between structure and language, theme, and topic. It is significant to examine this relationship more deeply and think Selvon's portrayal must be thought about. Lonely Londoners have considerable roles, but there is no room to explore them (Johansson \& Vinthagen, 2016, pp. 417-435). Instead, it is better to concentrate on defining the roles of these three characters: Moses, Bart, and Galahad, who observe portraits of their wandering encounters: how do they respond to the frustration many critics consider an integral part of the theme of the Indian West's movement? Memory has changed understanding the work of many critics and how it can be explicitly expressed by Selvon through language and structure (Bonds \& Inwood, 2016, pp. 715-733).

\section{CONCLUSION}

The post-colonial era is the times which experienced many changes in the mindset of the people. Although this era is stained with countless situations of extreme racism that was seen by the black people of London. This was shown very proficiently in the novel of Lonely Londoners. However this can be seen due to successful resistance that was implicated by the people and driven by the intellectual thinkers that have established solutions for every problem. The resistance was not an overnight process. Changing the mindset of the people is something that can take a lot of efforts and passion. As the resistance was taken as a fight for power by many of the Europeans which added to the difficulties that are supposed to be seen by the 
whole resistance against dominant culture, but the resistance was shown the success over time. Hence it can be concluded that the concept of raising your voice is very legitimate and is something which should always be considered albeit in the most peaceful manner possible.

\section{REFERENCE LIST}

Adams, E. C. (2017). Passive resistance: Hopi responses to Spanish contact and conquest. In European Intruders and Changes in Behaviour and Customs in Africa, America and Asia before 1800 (pp. 4155). Routledge.

Apple, M. W., \& Christian-Smith, L. K. (2017). The politics of the textbook. The politics of the textbook (pp. 121). Routledge.

Bonds, A., \& Inwood, J. (2016). Beyond white privilege: Geographies of white supremacy and settler colonialism. Progress in Human Geography, 40(6), 715-733.

Crane, D., Kawashima, N., \& Kawasaki, K. I. (2016). Culture and globalization theoretical models and emerging trends. In Global culture (pp. 11-36). Routledge.

Dutta, M. J. (2015). Decolonizing communication for social change: A culture-centered approach. Communication Theory, 25(2), 123-143.

Ellis, A. E. (2015). The imperfect longing: Sam Selvon's The Lonely Londoners and the dance of doubt. African and Black Diaspora: An International Journal, 8(2), 178-189.

Escobar, A. (2018). Culture, economics, and politics in Latin American social movements theory and research. In The making of social movements in Latin America (pp. 62-86). Routledge.

Johansson, A., \& Vinthagen, S. (2016). Dimensions of everyday resistance: An analytical framework. Critical Sociology, 42(3), 417-435.

Kapur, R. (2017). Postcolonial erotic disruptions: Legal narratives of culture, sex, and nation in India. In Popular Culture and Law (pp. 61-112). Routledge.

Liu, T. (2016). Hybridization in Political Civilization in Samuel Selvon's The Lonely Londoners and Moses Ascending. Theory and Practice in Language Studies, 6(5), 1006-1010.

Marshall, E. Z. (2016). 'Is Who Send We Up In This Place?'Threshold Paralysis and Postponed Arrivals in Sam Selvon's Lonely Londoners and George Lamming's The Emigrants. Literary London Journal, 13(1).

Mills, C. W. (2017). White supremacy. In The Routledge Companion to the Philosophy of Race (pp. 475487). Routledge.

Moss, P. (2017). Power and resistance in early childhood education: From dominant discourse to democratic experimentalism. Journal of Pedagogy, 8(1), 11-32.

Ungar, M. (2015). Resilience and culture: The diversity of protective processes and positive adaptation. In Youth resilience and culture (pp. 37-48). Springer, Dordrecht.

Wolfe, S. F. (2016). A Happy English Colonial Family in 1950s London?: Immigration, Containment and Transgression in The Lonely Londoners. Culture, Theory and Critique, 57(1), 121-136. 